\title{
Oxime bond-linked daunorubicin-GnRH-III bioconjugates exert antitumor activity in castration-resistant prostate cancer cells via the type I GnRH receptor
}

\author{
MARINA MONTAGNANI MARELLI ${ }^{1 *}$, MARILENA MANEA ${ }^{2,3^{*}}$, ROBERTA M. MORETTI $^{1}$, \\ MONICA MARZAGALLI $^{1}$ and PATRIZIA LIMONTA ${ }^{1}$ \\ ${ }^{1}$ Department of Pharmacological and Biomolecular Sciences, University of Milan, I-20133 Milan, Italy; \\ ${ }^{2}$ Department of Chemistry, ${ }^{3}$ Zukunftskolleg, University of Konstanz, D-78457 Konstanz, Germany
}

Received June 16, 2014; Accepted August 7, 2014

DOI: $10.3892 /$ ijo.2014.2730

\begin{abstract}
It is well established that gonadotropin-releasing hormone receptors (GnRH-R) are expressed in different types of cancers, including castration-resistant prostate cancer (CRPC) and mediate the antiproliferative effect of $\mathrm{GnRH}$ analogs. Thus, these compounds are employed as targeting moieties to selectively deliver chemotherapeutic agents to cancer cells. GnRH-III, the decapeptide isolated from the sea lamprey brain, has lower potency than GnRH in stimulating gonadotropin secretion, but it exerts antiproliferative effects on many tumors expressing the GnRH-R. GnRH-III-based peptides are considered promising targeting moieties for the preparation of anticancer drug delivery systems. These studies were aimed at i) evaluating the antitumor activity of two cytotoxic oxime bond-linked daunorubicin (Dau)-GnRH-III derivative bioconjugates (Dau-GnRH-III, in which daunorubicin was coupled to the ${ }^{8}$ Lys in the native form of GnRH-III, and Dau- $\left[{ }^{4}\right.$ Lys(Ac)]GnRH-III, in which daunorubicin was attached to the ${ }^{8} \mathrm{Lys}$ of a GnRH-III derivative where ${ }^{4}$ Ser was replaced by an acetylated lysine) on CRPC cells; and ii) to elucidate the involvement of the classical GnRH-R (type I GnRH-R) in this antitumor activity. Our results demonstrated that both Dau-GnRH-III and Dau- $\left[{ }^{4} \operatorname{Lys}(\mathrm{Ac})\right]-\mathrm{GnRH}$-III were rapidly internalized into DU145 prostate cancer cells and exerted a significant cytostatic effect. Both bioconjugates increased the levels of the active form of caspase-3, indicating the involvement of apoptosis in their antitumor activity. The antiproliferative
\end{abstract}

Correspondence to: Dr Patrizia Limonta, Department of Pharmacological and Biomolecular Sciences, University of Milan, I-20133 Milan, Italy

E-mail: patrizia.limonta@unimi.it

*Contributed equally

Key words: GnRH-III, daunorubicin, daunorubicin-GnRH-III bioconjugates, gonadotropin-releasing hormone receptor, castrationresistant prostate cancer effect of both Dau-GnRH-III and Dau-[ $\left.{ }^{4} \mathrm{Lys}(\mathrm{Ac})\right]-\mathrm{GnRH}-\mathrm{III}$ was counteracted by the simultaneous treatment of the cells with Antide, an antagonist of the GnRH-R. Moreover, after silencing the type I GnRH-R the antitumor activity of both bioconjugates was completely abolished. These data demonstrate that in CRPC cells, daunorubicin-GnRH-III derivative bioconjugates: i) inhibit tumor cell proliferation, by triggering the apoptosis process; ii) exert their antitumor effect through the activation of the type I GnRH-R expressed on these cells. Cytotoxic-GnRH-III derivative may represent promising targeted chemotherapeutics for the treatment of CRPC patients.

\section{Introduction}

The decapeptide gonadotropin-releasing hormone ( $\mathrm{GnRH}$, Glp-His-Trp-Ser-Tyr-Gly-Leu-Arg-Pro-Gly- $\mathrm{NH}_{2}$ ) was first identified as the key regulator of the pituitary-gonadal axis (1). It is synthesized in the hypothalamic neurons and then released, in a pulsatile manner, into the hypophyseal portal circulation to reach the anterior pituitary. By binding to its specific receptors (GnRH-R) on the pituitary gonadotropes, it stimulates the synthesis/release of the two gonadotropins and, subsequently, the steroid production from the gonads $(2,3)$.

In order to be activated, pituitary GnRH-R require pulsatile stimulation by GnRH. Moreover, it has been found that their sustained stimulation by GnRH agonists, after an initial flare event, leads to desensitization, with the consequent suppression of gonadotropin and steroid secretion. On the basis of this activity, GnRH agonists are successfully used for the treatment of different hormone-related pathologies, such as steroid-dependent tumors (prostate, breast and endometrial cancer) $(4,5)$.

It is now well established that GnRH-R are also expressed in different human cancer cells and tissues, where they are associated with a strong antitumor activity (antiproliferative/ antimetastatic/antiangiogenic) (6-10). These data indicate that, when utilized for the treatment of hormone-dependent cancers, in addition to their activity at the pituitary level, GnRH analogs may also exert a direct antitumor effect on cancer cells.

More recently, tumor GnRH-R have been considered as a promising molecular target for novel treatment strategies. Specifically, on the basis of their binding to the GnRH-R 
expressed on cancer cells, GnRH derivatives could be employed not only as anticancer agents, but could also serve as targeting moieties to deliver chemotherapeutic agents directly to cancer cells. This targeted drug delivery can be achieved by attaching a chemotherapeutic drug to a GnRH analog, either directly or through a chemically or enzymatically cleavable spacer. After binding to the GnRH receptors on cancer cells, the bioconjugate is internalized by receptor-mediated endocytosis and then processed at the lysosomal level, leading to the release of the free drug or to the formation of drug containing metabolites that further exert a cytotoxic effect. Thus, these cytotoxic GnRH-based bioconjugates act as drug delivery systems, specifically affecting the proliferation of cancer cells expressing the GnRH-R, which is the case of the majority of cancer cells, while sparing non-cancerous cells from the unnecessary exposure (11). The major advantage of this targeted chemotherapeutic approach is the increased selectivity of cytotoxic agents as well as their decreased peripheral toxicity. A crucial feature to be possessed by these compounds is their stability in the blood circulation in order to prevent an early drug release before targeting the cancer cells.

Cytotoxic GnRH-based bioconjugates were first developed in Schally's laboratory. The most potent compounds consisted of the GnRH derivative [D-Lys $\left.{ }^{6}\right]-\mathrm{GnRH}$ to which the chemotherapeutic agents doxorubicin (Dox) (AN-152, also known as AEZS-108) or 2-pyrrolino-Dox (AN-207) (11) were attached via an ester bond, through a glutarate spacer.

In addition to the classical GnRH, another isoform of the neurohormone, designed as GnRH-III, has been discovered. GnRH-III is a decapeptide (Glp-His-Trp-Ser-His-Asp-TrpLys-Pro-Gly- $\mathrm{NH}_{2}$, Glp is pyroglutamic acid) isolated from sea lamprey (Petromyzon marinus) that has 60\% homology with GnRH, with four different amino acids in positions 5-8 (Fig. 1). This GnRH isoform has lower potency than GnRH in stimulating gonadotropin secretion at the pituitary level and it exerts an antiproliferative effect on many types of cancer cells expressing the GnRH-R (12). On the basis of these features, GnRH-III derivatives are considered suitable tumor targeting moieties for the preparation of anticancer drug delivery systems. Recently, a panel of anthracycline-GnRH-III derivative bioconjugates has been designed, synthesized and biochemically characterized (13-16). The most promising cytotoxic compounds contained the anticancer drug daunorubicin (Dau) attached via an oxime bond to the Lys in position 8 of GnRH-III. Two of them, $\left[{ }^{4} \mathrm{Ser},{ }^{8} \mathrm{Lys}(\mathrm{Dau}=\mathrm{Aoa})\right]-\mathrm{GnRH}-\mathrm{III}$ (here denoted as Dau-GnRH-III), in which daunorubicin was coupled to the ${ }^{8} \mathrm{Lys}$ in the native form of GnRH-III, and $\left[{ }^{4}\right.$ Lys(Ac), ${ }^{8}$ Lys(Dau=Aoa)]-GnRH-III (here denoted as Dau-[ $\left.{ }^{4} \mathrm{Lys}(\mathrm{Ac})\right]-\mathrm{GnRH}-\mathrm{III}$, in which daunorubicin was attached to the ${ }^{8} \mathrm{Lys}$ of a GnRH-III derivative in which ${ }^{4} \mathrm{Ser}$ was replaced by an acetylated lysine $\left[{ }^{4} \mathrm{Lys}(\mathrm{Ac})\right]$ (Fig. 1) are of particular interest. They have been shown to exert significant in vitro cytostatic effect on cancer cells expressing GnRH-R, such as breast, colon and androgen-dependent prostate cancer cells and to be stable in human serum at least for $24 \mathrm{~h}$. In the presence of digestive enzymes, in particular chymotrypsin, Dau-[ ${ }^{4}$ Lys(Ac)]-GnRH-III proved to be more stable. This compound also exerted significant in vivo tumor growth inhibitory effect on colon carcinoma-bearing mice (14). Both bioconjugates were degraded by lysosomal enzymes, and
H-Lys(Dau=Aoa)-OH was identified as the smallest drugcontaining metabolite produced in the presence of rat liver lysosomal homogenate. This metabolite was able to bind to DNA in vitro, a result that could contribute to the understanding of the antitumor effect of the bioconjugates $(14,15)$.

It is hypothesized that these GnRH-III bioconjugates might exert their antitumor activity through the classical form of the GnRH-R; however, this issue has not been addressed in previous studies.

Prostate cancer is the most commonly diagnosed cancer for men and the second leading cause of cancer-related deaths among men in Western countries (17). Prostate cancer patients can be initially cured by radiotherapy or surgery; however, most of them will experience disease progression. In this phase, in which most tumors are dependent on the presence of androgens, androgen-deprivation therapy, aimed at blocking androgen secretion/activity, represents the most effective treatment (5). This therapy includes chemical castration, which can be achieved by GnRH agonists, given either alone or in combination with an antiandrogen $(5,18)$. However, after an excellent initial response, relapse occurs in most patients within a median of 2-3 years and the tumor progresses towards a condition of resistance to castration [castration-resistant prostate cancer (CRPC)]. For CRPC patients the therapeutic options are still very limited, since taxane-based (i.e., docetaxel) treatment can usually provide a progression-free survival of a few months $(19,20)$.

In Limonta's laboratory it has been widely demonstrated that GnRH receptors are expressed in CRPC cells (DU145 and PC3) and that their activation by means of GnRH agonists significantly reduces cancer cell proliferation and metastatic behavior (21-25). In line with these observations, GnRH-R have also been reported to be expressed in prostate cancer biopsies from patients who developed CRPC after orchiectomy and antiandrogen therapy $(26,27)$. These data strongly support the notion that the GnRH-R can represent an effective target for cytotoxic GnRH-based bioconjugates also in CRPC cells.

In the study reported here, we aimed to investigate whether the two oxime bond-linked daunorubicin-GnRH-III derivative bioconjugates, Dau-GnRH-III and Dau-[ ${ }^{4}$ Lys(Ac)]-GnRH-III, might affect the growth of castration-resistant DU145 and PC3 prostate cancer cells to elucidate the involvement of the classical GnRH-R (type I GnRH-R) in this antitumor activity.

Our results show that both bioconjugates significantly decrease CRPC cell proliferation and that this effect is completely counteracted by a classical GnRH-R antagonist (Antide) as well as by silencing the type I GnRH-R.

\section{Materiald and methods}

Materials. The GnRH agonist Zoladex [Goserelin acetate, D-Ser $\left.(\mathrm{tBu})^{6} \mathrm{Aza}-\mathrm{Gly}^{10}-\mathrm{GnRH}\right]$ was kindly provided by AstraZeneca Pharmaceuticals (Macclesfield, Cheshire, UK). The GnRH antagonist Antide (A8802) and MTT [3-(4,5-dimethylthiazol-2-yl)-2,5-diphenyl tetrazolium bromide] (M5655) were purchased from Sigma-Aldrich (Milan, Italy).

All amino acid derivatives, benzotriazole-1-yloxytrispyrrolidinophosphonium-hexafluoro-phosphate (PyBOP), Bis-Boc-aminooxyacetic acid (Bis-Boc-Aoa-OH) and Rink- 
$\mathbf{A}$

\section{GnRH-III}

Glp-His-Trp- ${ }^{-}$Ser-His-Asp-Trp- ${ }^{8}$ Lys-Pro-Gly- $\mathrm{NH}_{2}$

B

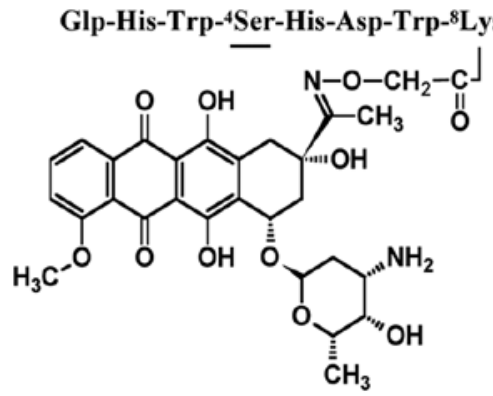

C

Glp-His-Trp- ${ }^{-}$Lys(Ac)-His-Asp-Trp- ${ }^{8}$ Lys-Pro-Gly-NH ${ }_{2}$

\section{Dau- $\left[{ }^{4} \operatorname{Lys}(\mathrm{Ac})\right]-$ GnRH-III}

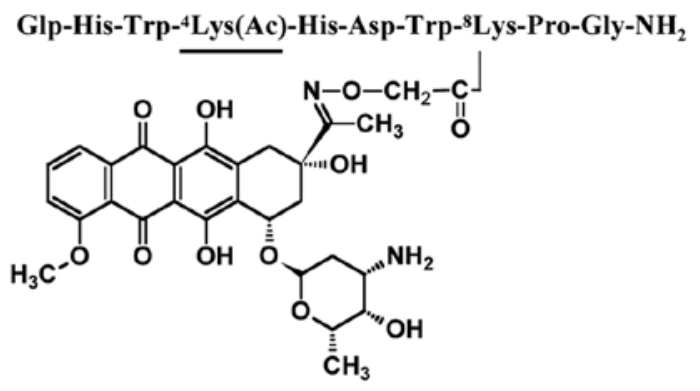

Figure 1. Structure representation of GnRH-III, [ $\left.{ }^{4} \mathrm{Lys}(\mathrm{Ac})\right]-\mathrm{GnRH}-\mathrm{III}$ and oxime bond-linked daunorubicin-GnRH-III derivative bioconjugates Dau-GnRH-III and Dau-[4'Lys(Ac)]-GnRH-III.

Amide MBHA resin were purchased from NovaBiochem (Läufelfingen, Switzerland). Scavengers, coupling agents and cleavage reagents [triisopropylsilane (TIS), 4-methylmorpholine (NMM), piperidine, 1,8-diazabicyclo[5.4.0]undec-7-ene (DBU), trifluoroacetic acid (TFA)] were obtained from SigmaAldrich (Taufkirchen, Germany). Solvents for peptide synthesis and purification were purchased from Acros Organics (Geel, Belgium) and Riedel deHaën (Seelze, Germany). All reagents and solvents were of analytical grade or highest available purity.

Synthesis and chemical characterization of GnRH-III and $\left[{ }^{4} \operatorname{Lys}(A c)\right]-G n R H$-III peptides and of daunorubicin containing bioconjugates. The peptides GnRH-III (Glp-His-Trp-Ser-HisAsp-Trp-Lys-Pro-Gly- $\mathrm{NH}_{2}$ ) and [ $\left.{ }^{4} \mathrm{Lys}(\mathrm{Ac})\right]-\mathrm{GnRH}$-III [Glp-His-Trp-Lys(Ac)-His-Asp-Trp-Lys-Pro-Gly- $\mathrm{NH}_{2}$ ] were prepared by solid phase synthesis on a Rink-Amide MBHA resin, according to Fmoc/tBu chemistry. For the synthesis of daunorubicin containing bioconjugates, a combination of solid phase peptide synthesis and chemoselective ligation in solution (oxime bond formation) was employed. For this purpose, the aminooxyacetylated derivatives of GnRH-III were first prepared: Glp-His-Trp-Ser-His-Asp-Trp-Lys(Aoa)-Pro-Gly- $\mathrm{NH}_{2}$ and Glp-His-Trp-Lys(Ac)-His-Asp-Trp-Lys(Aoa)-ProGly- $\mathrm{NH}_{2}$ (Aoa, aminooxyacetyl). Previously reported synthetic protocols were used $(14,15)$, with the following modifications: i) the removal of the Fmoc protecting group with $2 \%$ piperidine, $2 \% \mathrm{DBU}$ in DMF was performed for a shorter time $(3+7 \mathrm{~min})$ in order to avoid the succinimide formation from ${ }^{6} \mathrm{Asp}$; ii) the acetylation of the $\varepsilon$-amino group of ${ }^{4} \mathrm{Lys}$ was not performed on the resin as previously published; the FmocLys(Ac)-OH was incorporated during the solid phase peptide synthesis in the presence of PyBOP and NMM. The aminooxyacetylation of the $\varepsilon$-amino group of ${ }^{8} \mathrm{Lys}$ was performed on the resin using 5 equiv of Bis-Boc-Aoa/PyBOP/NMM (1:1:2 $\mathrm{v} / \mathrm{v} / \mathrm{v}$ ) in DMF for $60 \mathrm{~min}$. After completion of the synthesis of protected GnRH-III-based peptides, they were cleaved from the resin, simultaneously with the removal of the side chain protecting groups, using a mixture of $95 \%$ TFA, $2.5 \%$ water and $2.5 \%$ TIS, for $2.5 \mathrm{~h}$ at room temperature. Then, the peptides were precipitated with ice-cold diethyl ether, washed three times with diethyl ether and solubilized in $100 \%$ acetic acid prior to freeze drying. The crude products were purified by semi-preparative RP-HPLC and characterized by mass spectrometry, as previously published $(14,15)$. The attachment of daunorubicin to the aminooxyacetyated derivatives of GnRH-III was carried out in solution $(0.2 \mathrm{M}$ sodium acetate, $\mathrm{pH} 5.0$ ) at a peptide concentration of $10 \mu \mathrm{g} / \mu \mathrm{l}$ and using $30 \%$ excess of daunorubicin. The bioconjugates Dau-GnRH-III [Glp-His-Trp-Ser-His-Asp-Trp-Lys(Dau=Aoa)-Pro-Gly- $\mathrm{NH}_{2}$ ] and Dau-[ ${ }^{4}$ Lys(Ac)]-GnRH-III [Glp-His-Trp-Lys(Ac)-HisAsp-Trp-Lys(Dau=Aoa)-Pro-Gly-NH $\mathrm{NH}_{2}$ (Fig. 1) were purified by semi-preparative RP-HPLC and analyzed by ESI-ion trap mass spectrometry $(14,15)$.

Cell culture. The human DU145 and PC3 prostate cancer cell lines were purchased from American Type Culture Collection (Rockville, MD). Cells were grown in RPMI medium (Biochrom KG, Berlin, Germany) supplemented with $5 \%$ (DU145) or 7.5\% (PC3) fetal bovine serum (FBS; Life Technologies, Inc., Paisley, Scotland, UK), glutamine $(1 \mathrm{mM})$ and antibiotics (100 IU/ml penicillin $\mathrm{G}$ sodium and $100 \mu \mathrm{g} / \mathrm{ml}$ streptomycin sulfate) in a humidified atmosphere of $5 \% \mathrm{CO}_{2} / 95 \%$ air at $37^{\circ} \mathrm{C}$.

Cell proliferation studies. Preliminary experiments were performed to evaluate whether the peptides employed as targeting moieties, GnRH-III and its ${ }^{4}$ Lys-acetylated derivative, exert a significant antiproliferative effect on castration-resistant prostate cancer cells expressing the type I GnRH-R.DU145 cells $\left(5 \times 10^{4}\right.$ cells/dish) were plated in $100-\mathrm{mm}$ dishes. After 2 days, the cells were treated with GnRH-III, [ $\left.{ }^{4} \mathrm{Lys}(\mathrm{Ac})\right]-\mathrm{GnRH}-\mathrm{III}$ and Zoladex (a classical agonist of the type I GnRH-R, utilized as a control) at a dose of $10^{-6} \mathrm{M}$. The treatment was performed daily, for 6 days, as previously described (21). At the end of the 
treatments, cells were harvested and counted using a hemocytometer. Each experimental group consisted of four replicates, and each experiment was repeated three times.

Cellular uptake of bioconjugates determined by fluorescence microscopy. To evaluate the cellular uptake of the two bioconjugates, DU145 cells were seeded in 24-well plates in complete medium. After $24 \mathrm{~h}$ of incubation at $37^{\circ} \mathrm{C}$, cells were treated with Dau, Dau-GnRH-III or Dau-[ ${ }^{4}$ Lys(Ac)]-GnRH-III $(100 \mu \mathrm{M})$ for $3.5 \mathrm{~h}$. Taking advantage of the autofluorescence properties of daunorubicin at an excitation wavelength of $488 \mathrm{~nm}$, the cellular uptake of the three compounds was determined by fluorescence microscopy. At the end of the incubation period, cells were examined under a Zeiss Axiovert 200 microscope with a x20/1.4 objective lens linked to a Coolsnap Es CCD camera (Roper Scientific-Crisel Instruments, Rome, Italy).

In vitro cytostatic effect of bioconjugates determined by MTT assay. To evaluate the in vitro cytostatic effect of Dau-GnRH-III bioconjugates, DU145 cells ( $3 \times 10^{4}$ cells/well) were plated in 24-well plates and cultured in 5\% FBS-supplemented medium for $24 \mathrm{~h}$. Cells were then treated with Dau $\left(10^{-10}-10^{-6} \mathrm{M}\right.$, for 48 or $72 \mathrm{~h}$ ) or with the bioconjugates Dau-GnRH-III and Dau-[ ${ }^{4}$ Lys(Ac)]-GnRH-III $\left(10^{-8}-10^{-4} \mathrm{M}\right.$, for 48 or $\left.72 \mathrm{~h}\right)$. Cells treated with serum-free medium were used as a control. After treatment, the MTT [3-(4,5-dimethylthiazol-2-yl)-2,5-diphenyl tetrazolium bromide] assay was performed. Thus, MTT was added to each well (final concentration $0.5 \mathrm{mg} / \mathrm{ml}$ ) and during $1 \mathrm{~h}$ incubation at $37^{\circ} \mathrm{C}$ purple crystals were formed by mitochondrial dehydrogenase enzyme present in the living cells. After that, the supernatant was removed; the crystals were dissolved in $300 \mu \mathrm{l}$ of 2-Propanol (33539 Sigma) and the optical density (OD) was determined at $\lambda=550$ using an ELx80 Absorbance Microplate Reader (BioTek, Bedfordshire, UK).

Similar experiments were performed on human castrationresistant $\mathrm{PC} 3$ prostate cancer cells. To elucidate whether the two daunorubicin containing bioconjugates exert their cytostatic effect through the activation of the type I GnRH-R, DU145 cells were treated with Dau-GnRH-III or Dau-[ $\left.{ }^{4} \mathrm{Lys}(\mathrm{Ac})\right]-\mathrm{GnRH}-\mathrm{III}$ $\left(5 \times 10^{-6} \mathrm{M}\right.$, for $\left.48 \mathrm{~h}\right)$, either in the presence or in the absence of the GnRH antagonist Antide (a classical antagonist of the type I GnRH-R, $5 \times 10^{-6} \mathrm{M}$ ). The MTT assay was then performed as described above. Each experimental group consisted of four replicates and each experiment was repeated three times.

Analysis of caspase-3 activation by western blotting. DU145 cells were seeded in $100-\mathrm{mm}$ dishes $\left(5 \times 10^{5}\right.$ cells/dish). After $24 \mathrm{~h}$, cells were treated with Dau $\left(5 \times 10^{-8} \mathrm{M}\right)$ or with the bioconjugates $\left\{\right.$ Dau-GnRH-III and Dau- $\left[{ }^{4}\right.$ Lys(Ac)]-GnRH-III $\}$ at a concentration of $10^{-5} \mathrm{M}$ for 48 or $72 \mathrm{~h}$. At the end of the treatment, cells (both adherent and floating in the supernatant) were lysed in RIPA buffer $(0.05 \mathrm{M}$ Tris- $\mathrm{HCl} \mathrm{pH} 7.7,0.15 \mathrm{M}$ $\mathrm{NaCl}, 0.8 \%$ SDS, $10 \mathrm{mM}$ EDTA, $100 \mu \mathrm{M} \mathrm{NaVO}_{4}, 50 \mathrm{mM} \mathrm{NaF}$, $0.3 \mathrm{mM}$ PMSF, $5 \mathrm{mM}$ iodoacetic acid) containing leupeptin $(50 \mu \mathrm{g} / \mathrm{ml})$, aprotinin $(5 \mu \mathrm{l} / \mathrm{ml})$ and pepstatin $(50 \mu \mathrm{g} / \mathrm{ml})$. Protein concentration was determined by BCA assay, according to the manufacturer's instructions (Thermo Scientific, Rockford, IL). Protein extracts $(30 \mu \mathrm{g})$ were resuspended in sample buffer (0.5 M Tris-HCl pH 6.8, 20\% glycerol, $10 \%$ SDS, $0.2 \%$ $\beta$-mercaptoethanol, $0.05 \%$ bromophenol blue) and heated at $95^{\circ} \mathrm{C}$ for $5 \mathrm{~min}$. Following electrophoretic separation by SDS-PAGE, proteins were transferred onto nitrocellulose membranes. Membranes were blocked with 5\% non-fat dry milk prior to the overnight incubation at $4{ }^{\circ} \mathrm{C}$ with either the rabbit monoclonal caspase-3 antibody (no. 9665, Cell Signaling Technology, Danvers, MA) or the rabbit monoclonal cleaved caspase-3 antibody (no. 9664, Cell Signaling Technology). Detection was performed using a horseradish peroxidaseconjugated anti-rabbit secondary antibody and enhanced chemiluminescence reagents (GE Healthcare Life Sciences, Milan, Italy).

Actin expression was evaluated as a loading control. Goat anti-human actin (SC-1616) antibody was from Santa Cruz Biotechnology (Santa Cruz, CA). Detection was performed using a horseradish peroxidase-conjugated anti-rabbit secondary antibody and enhanced chemiluminescence reagents (Supersignal Chemiluminescence Detection System, Thermo Scientific). The experiments were repeated three times.

Type I GnRH-R silencing. To investigate the role of the type I GnRH-R in the cytostatic activity of Dau-GnRH-III derivative bioconjugates, siRNA experiments were carried out. Type I GnRH-R small interfering RNAs were purchased from Invitrogen (Burlington, ON, Canada). Their sequences were as follows: type I GnRH-R-S (5'-UUGCAGAGUAACUCUCCAG CAUACC-3') and type I GnRH-R-AS (5'-GGUAUGCUGG AGAGUUACUCUGCAA-3'). A non-specific scrambled siRNA was used as a control (Medium GC Duplex, Invitrogen). Transfections were performed using Lipofectamine 2000 (Invitrogen) as a transfectant (according to the manufacturer's instructions). The transfection efficiency was assessed using the Block-it Alexa fluor red fluorescent oligo and it was usually $>70 \%$ of total cells. The effective knockdown of type I GnRH-R after siRNA transfections was monitored by RT-PCR.

For this purpose, DU145 cells were seeded in $60-\mathrm{mm}$ dishes $\left(2 \times 10^{5}\right.$ cells/dish). After three days, cells were transfected with type I GnRH-R siRNA or with scrambled siRNA at a final concentration of $150 \mathrm{nM}$, for $24 \mathrm{~h}$. Reverse transcription was performed on $2 \mu \mathrm{g}$ total RNA, as previously described (25), and cDNA synthesis was performed using the Gene AMP kit (Perkin-Elmer Cetus, Norwalk, CT) with an oligo(dt $)_{16}$ as a primer. PCR was carried out for 30 cycles $\left(95^{\circ} \mathrm{C}\right.$ for $60 \mathrm{sec}, 58^{\circ} \mathrm{C}$ for $60 \mathrm{sec}, 72^{\circ} \mathrm{C}$ for $120 \mathrm{sec})$, in the presence of the following primers: upstream primer, 5'-GACCTTGTCTGGAAAGATCC-3' (50 pmol) and downstream primer 5'-CAGGCTGATCACCACCATCA-3' (50 pmol) (25). The amplified cDNA products were separated on $1.5 \%$ agarose gels stained with ethidium bromide and visualized under UV light. The experiments were repeated three times.

Cytostatic assays after type I GnRH-R silencing. DU145 cells were seeded $\left(4.5 \times 10^{4}\right.$ cells/well $)$ in 24 -well plates and after $24 \mathrm{~h}$ the cells were transfected with either type I GnRH-R siRNA or with scrambled siRNA. After $24 \mathrm{~h}$, cells were treated with Dau-GnRH-III or Dau-[ ${ }^{4}$ Lys(Ac)]-GnRH-III $\left(10^{-5} \mathrm{M}\right)$ for $48 \mathrm{~h}$. The evaluation of cell growth was done by MTT assay, as described above. Each experimental group consisted of four replicates and each experiment was repeated three times. 


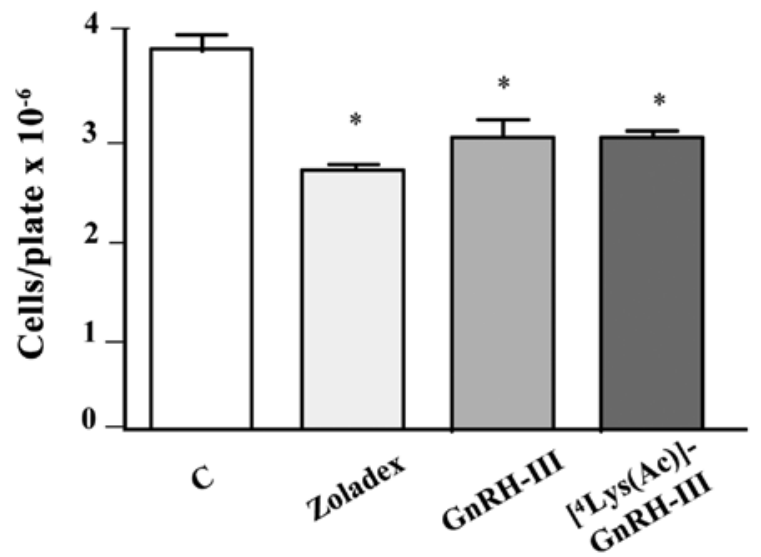

Figure 2. GnRH-III, its derivative $\left[{ }^{4} \mathrm{Lys}(\mathrm{Ac})\right]-\mathrm{GnRH}-\mathrm{III}$ and Zoladex (a classical GnRH agonist) exert an antiproliferative effect on DU145 cells. Cells were treated daily, for 6 days, with GnRH-III, $\left[{ }^{4} \mathrm{Lys}(\mathrm{Ac})\right]-\mathrm{GnRH}-\mathrm{III}$ and Zoladex (utilized as a positive control), at a dose of $10^{-6} \mathrm{M}$. At the end of the treatments, cells were harvested and counted using a hemocytometer. The results are presented as the mean \pm SEM. Each experimental group consisted of four replicates and each experiment was repeated three times. " $\mathrm{P}<0.05$ vs. C (untreated controls).

Statistical analysis. Results of proliferation and MTT studies were analyzed by one-way ANOVA followed by Bonferroni's test.

\section{Results}

Synthesis and chemical characterization of GnRH-III and [ $\left.{ }^{4} \operatorname{Lys}(A c)\right]-G n R H$-III peptides and of daunorubicin containing bioconjugates. The peptides GnRH-III and [ $\left.{ }^{4} \mathrm{Lys}(\mathrm{Ac})\right]-$ GnRH-III were prepared by solid phase peptide synthesis according to Fmoc/tBu chemistry, purified by RP-HPLC and analyzed by ESI-ion trap mass spectrometry $\{\mathrm{GnRH}-\mathrm{III}$ : $\mathrm{MW}($ calc $)=1259.35 ; \mathrm{MW}(\exp )=1259.10 ;\left[{ }^{4} \mathrm{Lys}(\mathrm{Ac})\right]-\mathrm{GnRH}-\mathrm{III}$ : $\mathrm{MW}($ calc $)=1342.48 ; \mathrm{MW}(\exp )=1342.0\}$.

The bioconjugates Dau-GnRH-III and Dau-[ ${ }^{4}$ Lys(Ac)]GnRH-III were synthesized by a combination of solid phase peptide synthesis and chemoselective ligation in solution. The oxime bond was formed between the oxo group at the C-13 position of daunorubicin and the aminooxyacetylated ${ }^{8}$ Lys of GnRH-III derivative peptides. The bioconjugates were purified by RP-HPLC and analyzed by ESI-ion trap mass spectrometry \{Dau-GnRH-III: MW $($ calc $)=1841.91 ; M W(\exp )=1841.65$; Dau-[ ${ }^{4}$ Lys (Ac)]-GnRH-III: $\quad M W($ calc $)=1925.05$; $\mathrm{MW}(\exp )=1924.70\}$.

Antiproliferative effect of GnRH-III and $\left[{ }^{4} \mathrm{Lys}(\mathrm{Ac})\right]-\mathrm{GnRH}-\mathrm{III}$ peptides on DU145 prostate cancer cells. First experiments were performed to evaluate the antitumor activity, on castrationresistant prostate cancer cells, of the carrier decapeptides used for the synthesis of daunorubicin containing bioconjugates. DU145 cells were treated daily, for 6 days, with GnRH-III, [ $\left.{ }^{4} \mathrm{Lys}(\mathrm{Ac})\right]-\mathrm{GnRH}$-III or with Zoladex (a specific agonist of the classical form of $\mathrm{GnRH}$, utilized as a positive control), at a dose of $10^{-6} \mathrm{M}$. At the end of the treatments, cells were counted using a hemocytometer. As shown in Fig. 2, both GnRH-III and its derivative $\left[{ }^{4} \mathrm{Lys}(\mathrm{Ac})\right]-\mathrm{GnRH}$-III exerted a significant antiproliferative effect on DU145 cells; in agreement with our previous data, similar results were obtained after treating the cells with the GnRH agonist Zoladex (21). When the treatment of the cells with the three decapeptides was performed for a shorter time interval (3 days) the proliferation of the cells was not affected (data not shown). These observations are in line with our previous data demonstrating that, in DU145 cells, GnRH agonists can exert a significant antiproliferative effect only when the treatments are performed for long time intervals (4-7 days) (21). The cytostatic activity of GnRH-III on castration-resistant $\mathrm{PC} 3$ prostate cancer cells has previously been demonstrated (28).

Cellular uptake of Dau-GnRH-III and Dau- $\left[{ }^{4} L y s(A c)\right]-$ GnRH-III bioconjugates into DU145 cells. The cellular uptake of the daunorubicin-GnRH-III derivative bioconjugates was investigated by fluorescence microscopy, taking advantage of the fluorescence properties of daunorubicin. DU145 cells were treated with Dau, Dau-GnRH-III or Dau-[ $\left.{ }^{4} \mathrm{Lys}(\mathrm{Ac})\right]-$ GnRH-III, at a concentration of $100 \mu \mathrm{M}$, for $3.5 \mathrm{~h}$. At the end of the treatment, cells were examined under a Zeiss Axiovert fluorescence microscope. As shown in Fig. 3, cells treated with Dau, Dau-GnRH-III or Dau-[ $\left[{ }^{4}\right.$ Lys(Ac)]-GnRH-III displayed intense fluorescent staining, indicating that not only Dau but also the two daunorubicin-GnRH-III bioconjugates are internalized into the cells.

Cytostatic effect of Dau-GnRH-III and Dau- $\left[{ }^{4} L y s(A c)\right]-$ GnRH-III bioconjugates on DU145 cells. The cytostatic effect of the daunorubicin-GnRH-III derivative bioconjugates was determined by MTT assay. DU145 cells were treated with daunorubicin (Dau, $10^{-10}-10^{-6} \mathrm{M}$ ) or with the bioconjugates Dau-GnRH-III and Dau-[ ${ }^{4}$ yys(Ac)]-GnRH-III $\left(10^{-8}-10^{-4} \mathrm{M}\right)$ for 48 or 72 h. Daunorubicin exerted a significant and dosedependent cytostatic effect on DU145 cells even at low doses $\left(5 \times 10^{-9} \mathrm{M}\right)$, this result being in line with the ability of the drug to freely diffuse into the cells. The two bioconjugates displayed a dose-dependent cytostatic effect at both tested time intervals; however, at higher doses than those of free daunorubicin, both at $48 \mathrm{~h}$ (Fig. 4A) and at $72 \mathrm{~h}$ (Fig. 4B). This provides an indication of the mechanism of action of the bioconjugates that require binding to the $\mathrm{GnRH}$ receptors before being internalized and further processed in the cells, at lysosomal level. $\mathrm{The} \mathrm{IC}_{50}$ values corresponding to these cytostatic effects at $72 \mathrm{~h}$ were as follows: $0.002 \pm 1.45 \mu \mathrm{M}$ for daunorubicin, $7.18 \pm 1.12 \mu \mathrm{M}$ for Dau-GnRH-III and $3.796 \pm 1.20 \mu \mathrm{M}$ for Dau- $\left[{ }^{4}\right.$ Lys(Ac)]-GnRH-III, respectively. These data indicate that the replacement of ${ }^{4} \mathrm{Ser}$ by Lys(Ac) led to an increased cytostatic effect in these cells.

Dau-GnRH-III and Dau-[4Lys(Ac)]-GnRH-III bioconjugates induce apoptosis in DU145 cells. To gain insight into the involvement of apoptosis in the antitumor activity of Dau-GnRH-III and Dau-[ ${ }^{4}$ Lys(Ac)]-GnRH-III on DU145 cells, we investigated the effects of the two bioconjugates on the activation of caspase-3. Cells were treated with free daunorubicin $\left(5 \times 10^{-8} \mathrm{M}\right)$, Dau-GnRH-III or Dau-[ ${ }^{4}$ Lys(Ac) $]-G n R H-I I I$ $\left(10^{-5} \mathrm{M}\right)$ for 48 or $72 \mathrm{~h}$. The protein expression of pro-caspase-3 and cleaved (active) caspase- 3 was then assessed by western blotting. As shown in Fig. 5, the total levels of pro-caspase-3 did not change throughout the treatments. Daunorubicin 

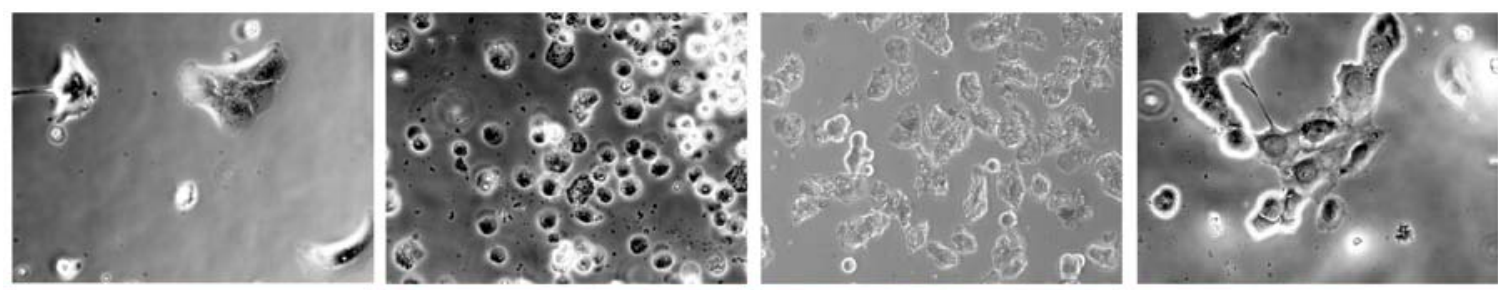

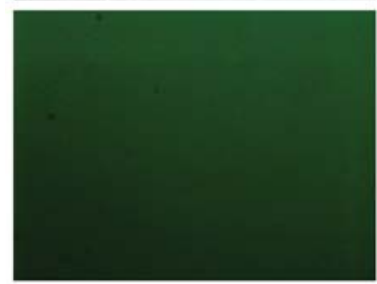

Control

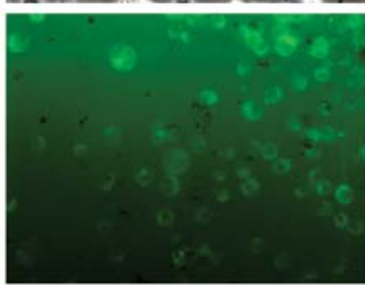

Dau

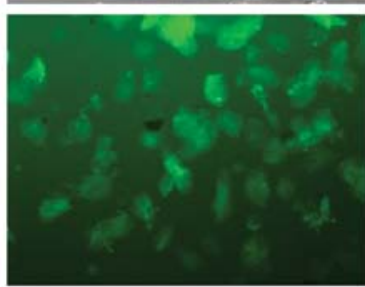

Dau-GnRH-III

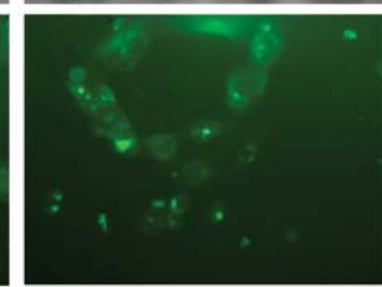

Dau-[ $\left.{ }^{4} \operatorname{Lys}(A c)\right]-G n R H-I I I$

Figure 3. Dau-GnRH-III and Dau-[ ${ }^{4}$ Lys(Ac)]-GnRH-III are taken up into DU145 cells. These experiments were performed taking advantage of the fluorescence properties of daunorubicin (Dau). DU145 cells were incubated with Dau, Dau-GnRH-III and Dau-[ $\left.{ }^{4} \mathrm{Lys}(\mathrm{Ac})\right]-\mathrm{GnRH}-\mathrm{III}$, at a concentration of $100 \mu \mathrm{M}$, for $3.5 \mathrm{~h}$. The cellular uptake of the three compounds was evaluated by fluorescence microscopy. One representative of three different experiments is shown.

\section{A DU145 $(48 \mathrm{~h})$}
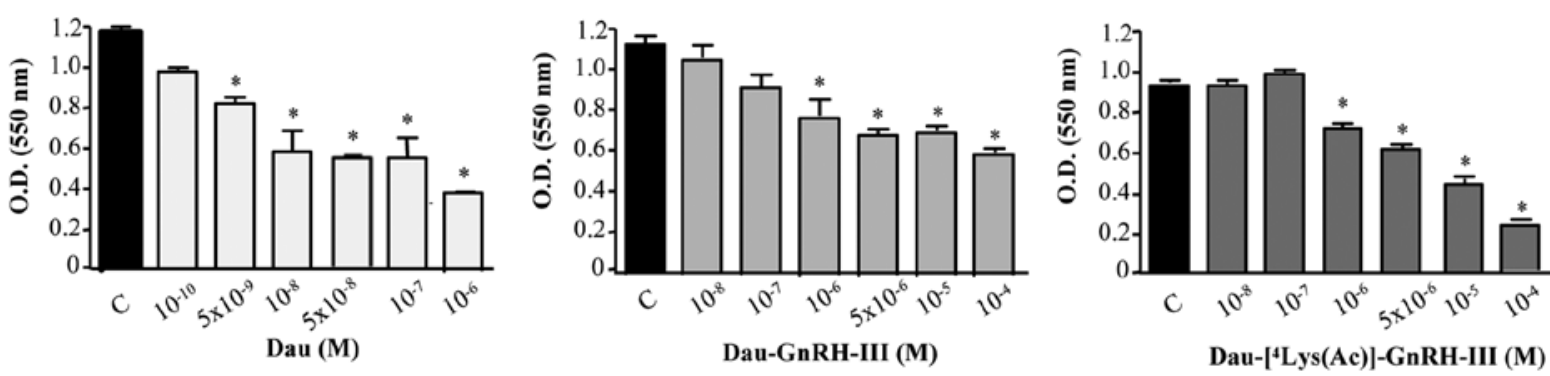

\section{B DU145 $(72 \mathrm{~h})$}
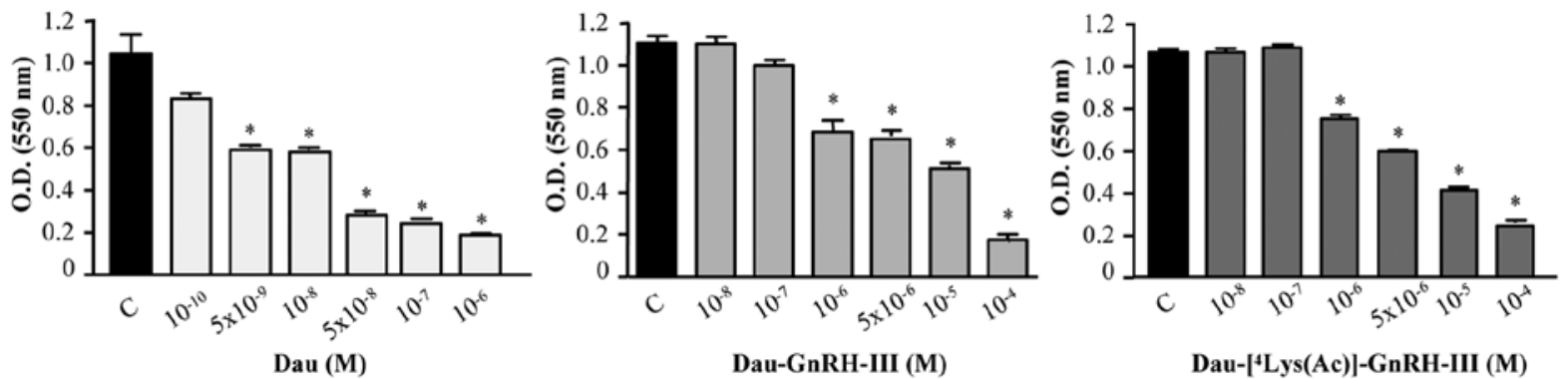

Figure 4. Dau-GnRH-III and Dau- $\left[{ }^{4} \mathrm{Lys}(\mathrm{Ac})\right]-\mathrm{GnRH}-\mathrm{III}$ exert a cytostatic effect on DU145 cells. DU145 cells were treated with daunorubicin (Dau) $\left(10^{-10}-10^{-6} \mathrm{M}\right)$ or with Dau-GnRH-III and Dau- $\left[{ }^{4} \mathrm{Lys}(\mathrm{Ac})\right]-\mathrm{GnRH}-\mathrm{III}\left(10^{-8}-10^{-4} \mathrm{M}\right)$ for 48 (panel A) or $72 \mathrm{~h}$ (panel B). At the end of the treatments, the cytostatic effect of the three compounds was determined by MTT assay. The results are presented as the mean \pm SEM. Each experimental group consisted of four replicates and each experiment was repeated three times. ${ }^{*} \mathrm{P}<0.05$ vs. $\mathrm{C}$ (untreated controls).

remarkably induced pro-caspase- 3 activation at both time intervals; the two bioconjugates conspicuously increased the levels of cleaved caspase-3 after $72 \mathrm{~h}$ of treatment (Fig. 5).

The antitumor effect of Dau-GnRH-III and Dau-[ $\left[{ }^{4} \mathrm{Lys}(\mathrm{Ac})\right]-$ GnRH-III bioconjugates on DU145 cells is mediated by the type I $G n R H-R$. Experiments were performed to investigate whether the two bioconjugates Dau-GnRH-III and Dau-[ ${ }^{4}$ Lys(Ac)]-GnRH-III might exert their antitumor effect through the activation of the type I GnRH-R. For this purpose, we first treated DU145 cells with the two bioconjugates $\left(5 \times 10^{-6} \mathrm{M}\right)$, either alone or in the presence of the GnRH antagonist Antide (a classical antagonist of the type I GnRH-R). The effect of the treatment was then evaluated by MTT assay, which showed that both bioconjugates significantly reduced the growth of DU145 cells. When administered alone, the GnRH antagonist Antide did not affect cell proliferation, as previously reported (21). On the other hand, Antide completely counteracted the antiproliferative effect of the two bioconjugates (Fig. 6). 
$48 \mathrm{~h}$
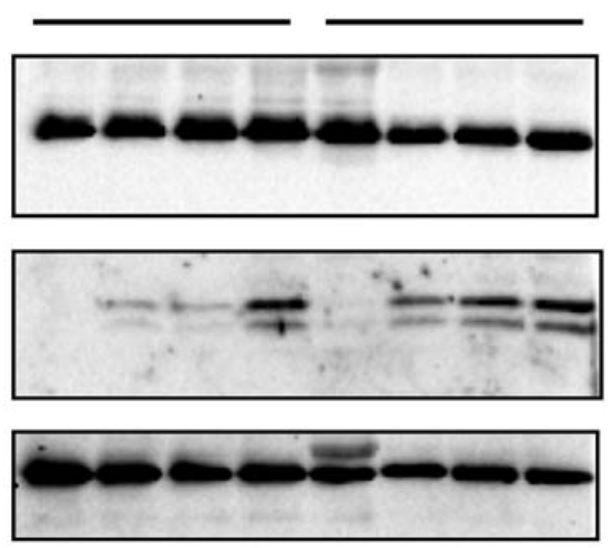

Actin

\section{Caspase-3}

\section{Cleaved caspase-3}

with the specific siRNA) were then treated with Dau-GnRH-III or with Dau-[ $\left.{ }^{4} \mathrm{Lys}(\mathrm{Ac})\right]-\mathrm{GnRH}-\mathrm{III}$ for $48 \mathrm{~h}$; the effect of the treatments on the cell growth was evaluated by MTT assay. As depicted in Fig. 7, panel B, in untransfected control cells (in the presence of the transfectant lipofectamine alone) as well as in cells transfected with the scrambled siRNA, both bioconjugates significantly reduced the cell growth. The antiproliferative effect of both compounds was completely abrogated in DU145 cells transfected with the specific type I GnRH-R siRNA (Fig. 7B).

Cytostatic effect of Dau-GnRH-III and Dau- $\left[{ }^{4} L y s(A c)\right]-$ GnRH-III bioconjugates on PC3 cells. These experiments were performed with the aim of confirming the cytostatic activity of oxime bond-linked daunorubicin-GnRH-III derivative bioconjugates on castration-resistant prostate cancer cells. For this purpose, PC3 cells were treated with free daunorubicin (Dau, $10^{-10}-10^{-6} \mathrm{M}$ ) or with the two bioconjugates Dau-GnRH-III and Dau-[ [ Lys(Ac)]-GnRH-III $\left(10^{-8}-10^{-4} \mathrm{M}\right.$, for 48 or $72 \mathrm{~h}$ ). The effect of the treatments on the cell growth was determined by MTT assay. Daunorubicin exerted a significant and dose-dependent antiproliferative effect on PC 3 cells. Moreover, both daunorubicin-GnRH-III derivative bioconjugates dose-dependently inhibited PC 3 cell growth both at 48 (Fig. 8A) and $72 \mathrm{~h}$ (Fig. 8B) of treatment. The $\mathrm{IC}_{50}$ values at $72 \mathrm{~h}$ were as follows: $1.54 \pm 1.25 \mu \mathrm{M}$ for daunorubicin, $93.4 \pm 1.3 \mu \mathrm{M}$ for Dau-GnRH-III and $60.4 \pm 1.53 \mu \mathrm{M}$ for Dau-[ $\left.{ }^{4} \operatorname{Lys}(\mathrm{Ac})\right]-\mathrm{GnRH}-\mathrm{III}$, respectively. These data confirm that Dau-GnRH-III and Dau-[ $\left[{ }^{4} \mathrm{Lys}(\mathrm{Ac})\right]-\mathrm{GnRH}-\mathrm{III}$ exert a significant antiproliferative activity on castration-resistant prostate cancer cells. However, it must be noted that PC 3 cells seem to be less responsive to the treatments than DU145; this may be due to the fact that PC 3 cells are more resistant to apoptosis, due to the lack of expression of the two oncosuppressor proteins p53 and PTEN (29).

\section{Discussion}

It is now well established that GnRH-R (type I, the classical form of GnRH-R) are expressed in several types of cancer cells (untransfected, transfected with a scramble siRNA or
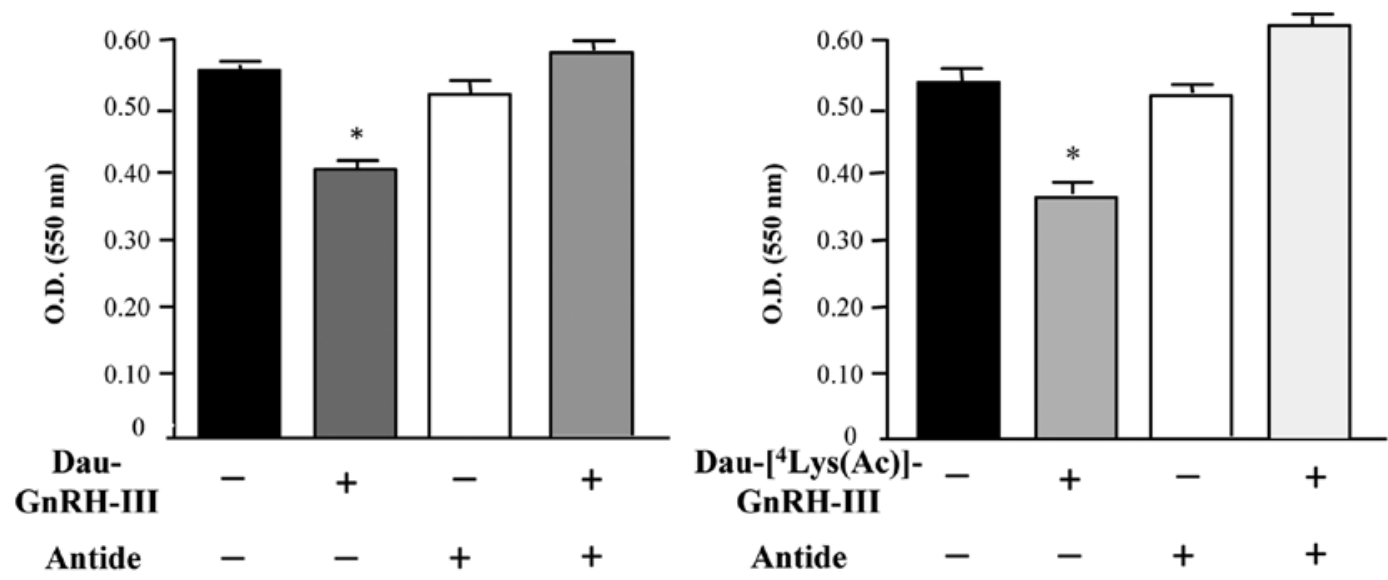

Figure 6. The antitumor effect of Dau-GnRH-III and Dau-[ $\left.{ }^{4} \mathrm{Lys}(\mathrm{Ac})\right]-\mathrm{GnRH}-\mathrm{III}$ bioconjugates on DU145 cells is mediated by the type I GnRH-R: MTT experiments. DU145 cells were treated with Dau-GnRH-III (left panel) or with Dau- $\left[{ }^{4} \mathrm{Lys}(\mathrm{Ac})\right]-\mathrm{GnRH}-\mathrm{III}$ (right panel), at a dose of $5 \times 10^{-6} \mathrm{M}$, for $48 \mathrm{~h}$, either in the absence or in the presence of the GnRH antagonist Antide (a classical antagonist of the type I GnRH-R, 5x10 ${ }^{-6} \mathrm{M}$ ). The results are presented as the mean \pm SEM. Each experimental group consisted of four replicates and each experiment was repeated three times. ${ }^{*} \mathrm{P}<0.05$ vs. C (untreated controls). 
$\mathbf{A}$

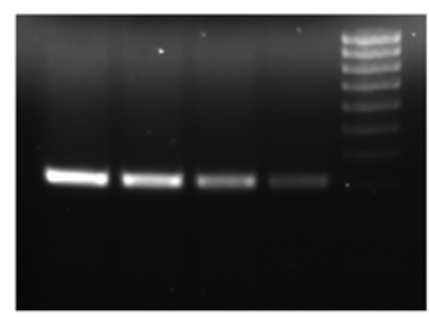

$\begin{array}{lllll}1 & 2 & 3 & 4 & \mathrm{M}\end{array}$

1- Control

2- Lipofectamine

3- Scrambled siRNA

4- GnRH-R siRNA

M- Marker EZ load 100 bp
B

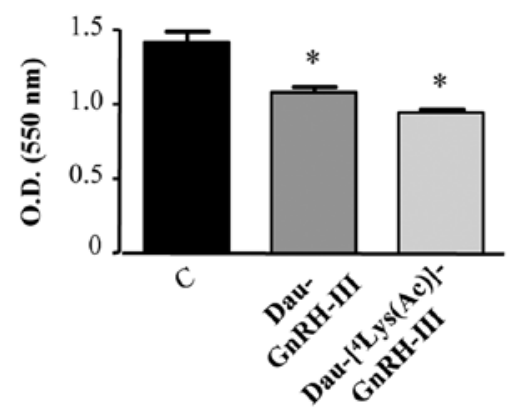

Scrambled siRNA

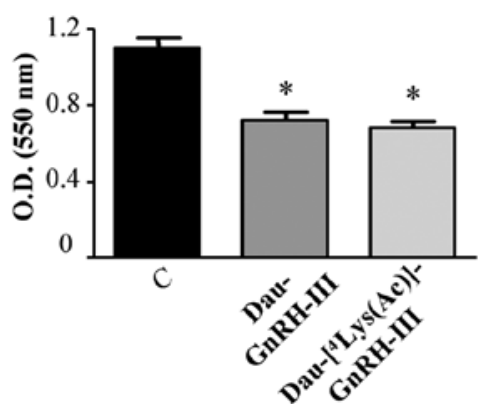

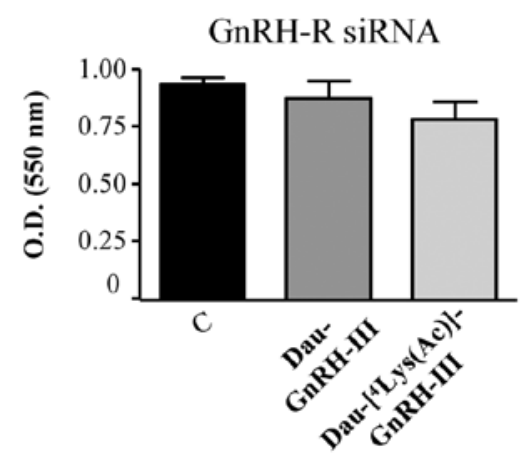

Figure 7. The antitumor effect of Dau-GnRH-III and Dau-[ $\left.{ }^{4} \mathrm{Lys}(\mathrm{Ac})\right]-\mathrm{GnRH}-\mathrm{III}$ bioconjugates on DU145 cells is mediated by the type I GnRH-R: siRNA experiments. DU145 cells were transfected either with a scrambled siRNA or with a siRNA specific for the type I GnRH-R, using Lipofectamine 2000 as a transfectant. The effective knockdown of the receptor was monitored by RT-PCR (panel A). After transfection (24 h), DU145 cells, transfected either with the scramble siRNA or with the siRNA specific for the type I GnRH-R, were treated with Dau-GnRH-III or Dau- $\left[{ }^{4} \mathrm{Lys}(\mathrm{Ac})\right]-\mathrm{GnRH}-\mathrm{III}\left(10^{-5} \mathrm{M}\right)$ for $48 \mathrm{~h}$. The evaluation of cell growth was done by MTT assay. Untransfected: control cells, with Lipofectamine without siRNA transfection. Each experimental group consisted of four replicates and each experiment was repeated three times. ${ }^{*} \mathrm{P}<0.05$ vs. C (untreated controls).

\section{A $\mathrm{PC} 3(48 \mathrm{~h})$}
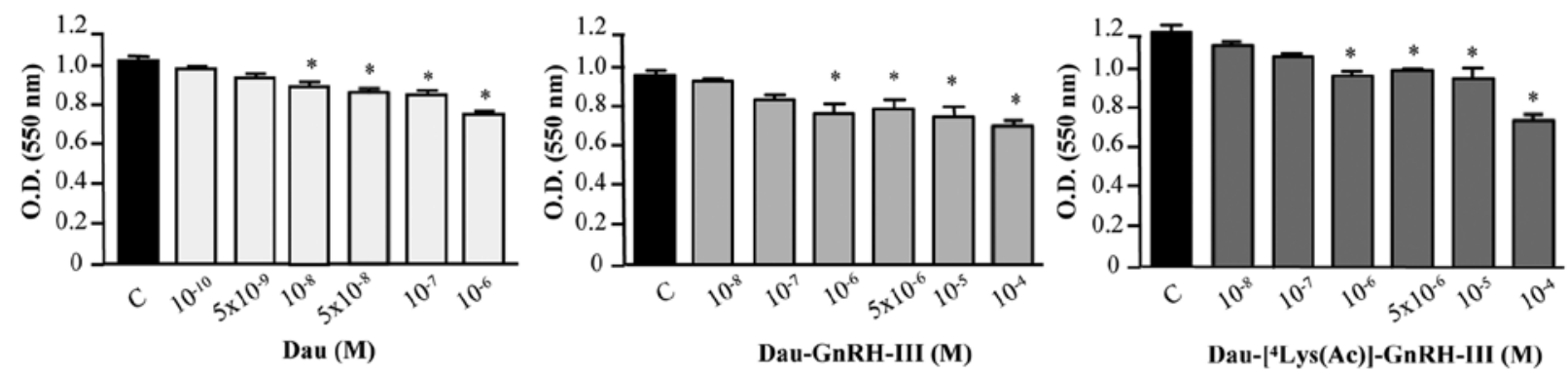

\section{B $\mathrm{PC} 3(72 \mathrm{~h})$}

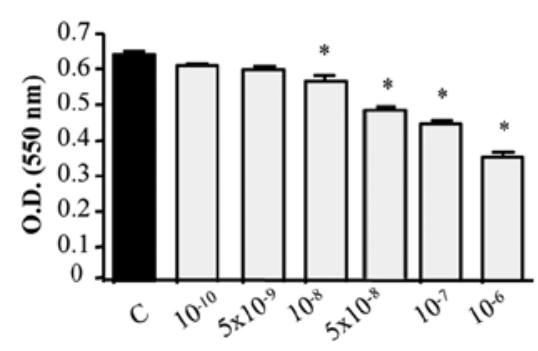

Dau (M)

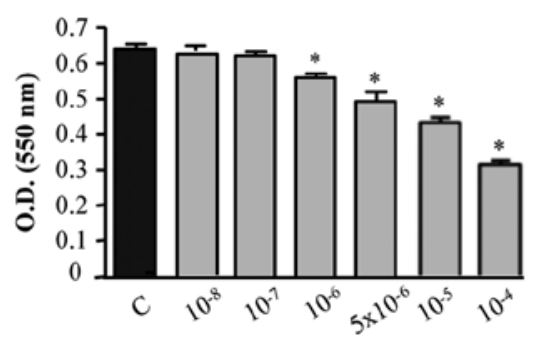

Dau-GnRH-III (M)

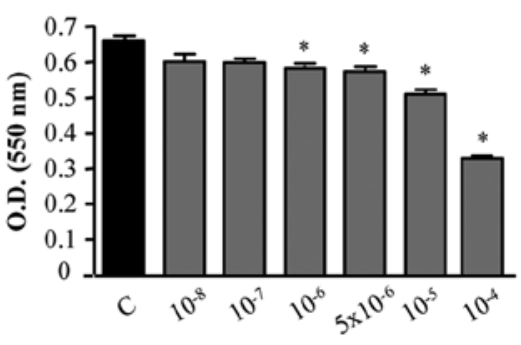

Dau- $\left[{ }^{4}\right.$ Lys(Ac)]-GnRH-III (M)

Figure 8. Dau-GnRH-III and Dau-[4Lys(Ac)]-GnRH-III exert a cytostatic effect on PC3 cells. PC3 cells were treated with Dau $\left(10^{-10}-10^{-6} \mathrm{M}\right)$ or with Dau-GnRH-III and Dau- $\left[{ }^{4} \mathrm{Lys}(\mathrm{Ac})\right]-$ GnRH-III $\left(10^{-8}-10^{-4} \mathrm{M}\right)$ for 48 (panel A) or $72 \mathrm{~h}$ (panel B) (as described for DU145 cells). At the end of the treatments, the cytostatic effect of the three compounds was evaluated by MTT assay. The results are presented as the mean \pm SEM. Each experimental group consisted of four replicates and each experiment was repeated three times. ${ }^{*} \mathrm{P}<0.05$ vs. $\mathrm{C}$ (untreated controls). 
cells and tumors, both related and unrelated to the reproductive system, and are associated with a significant antitumor activity $(6,7,9,10)$. These observations strongly support the notion that this receptor might represent an important molecular target for cytotoxic anticancer drug-GnRH derivative bioconjugates. The rationale for this treatment strategy is that the GnRH analog will act as a targeting moiety and specifically deliver the cytotoxic agents to malignant tissues, thus increasing their local efficacy, while limiting the peripheral toxicity. In line with this concept, the doxorubicin-[D-Lys $\left.{ }^{6}\right]-\mathrm{GnRH}$ bioconjugate, AEZS-108 (formerly known as AN-152), in which the chemotherapeutic drug was attached to the GnRH derivative through an ester bond, via a glutarate spacer, was developed. This bioconjugate was shown to inhibit the growth of breast, endometrial and ovarian cancer cells both in vitro and in preclinical studies (30); moreover, phase I/II clinical trials reported the efficacy and safety of AEZS-108 in patients with gynecological cancers $(11,31)$. However, mild side effects such as leukopenia and neutropenia as well as a reduction in the plasma levels of LH and FSH were also reported. These side effects were mainly attributed to the cleavage of the ester bond in circulation, leading to the release of free Dox and [D- ${ }^{6}$ Lys(glutarate)]-GnRH-I; the half-life of AESZ-108 was estimated to be about $2 \mathrm{~h}$. AEZS-108 is at present in phase III studies in advanced endometrial cancer positive for GnRH-R (30). Recently, this compound has been shown to exert a cytotoxic effect on human urinary bladder, glioblastoma and pancreatic cancer cells, in vitro and in vivo (32-34).

At present, various research studies are focused on the development of cytotoxic bioconjugates with increased chemical and enzymatic stability in circulation (i.e., in human serum) and with enhanced antitumor activity. A promising peptide to be used as a targeting moiety for the preparation of anticancer drug delivery systems is lamprey GnRH-III. It has been shown that this natural isoform of $\mathrm{GnRH}$ has a low potency at the pituitary level, while it exerts a strong antitumor activity on cancer cells expressing the GnRH-R (12). Thus, in our studies, GnRH-III decapeptide was employed as a targeting moiety, to which the chemotherapeutic agent daunorubicin was attached via an oxime bond to the Lys in position $8(13,15)$. Furthermore, the replacement of ${ }^{4} \mathrm{Ser}$ by Lys(Ac) led to a daunorubicin containing bioconjugate with enhanced cellular uptake, in vitro and in vivo antitumor activity (especially on colon carcinoma) and increased stability against digestive enzymes, in particular chymotrypsin (14). Both compounds, Dau-GnRH-III and Dau-[ ${ }^{4}$ Lys(Ac)]-GnRH-III, were stable in human serum for at least $24 \mathrm{~h}$, but degradable in the presence of rat liver lysosomal homogenate. Thus, these cytotoxic bioconjugates are promising drug delivery systems for targeted cancer chemotherapy.

The aim of the study reported here was to investigate whether cytotoxic GnRH-III-based bioconjugates might affect the growth of CRPC cells and to elucidate whether the type I GnRH-R (the classical form of the GnRH-R in humans) might mediate their effect. At present, the therapeutic options for CRPC patients are still very limited. Therefore, the identification of novel molecular markers as well as the development of more effective targeted treatment strategies, such as cytotoxic compounds specifically delivered at the level of the tumor, might help increasing the treatment options for these patients $(19,20)$.
Limonta's laboratory has widely reported that GnRH-R are expressed in human CRPC cells (DU145 and PC3), and their activation significantly reduces cell proliferation/invasiveness/ migration (21-25).

By fluorescence microscopy, taking advantage of the fluorescence properties of daunorubicin, we first demonstrated that both Dau-GnRH-III derivative bioconjugates were internalized into DU145 prostate cancer cells. Treatment of these cells with both compounds induced a dose-dependent and significant antiproliferative effect, with Dau-[ $\left.{ }^{4} \mathrm{Lys}(\mathrm{Ac})\right]-\mathrm{GnRH}-\mathrm{III}$ being more effective that Dau-GnRH-III, as indicated by the $\mathrm{IC}_{50}$ values. A cytostatic effect of the two bioconjugates was also observed in human PC3 CRPC cells. In both cell lines, the $\mathrm{IC}_{50}$ values for the cytostatic effect of free daunorubicin were much lower than those calculated for the bioconjugates, confirming the notion that the chemotherapeutic drug could freely diffuse into the cells, while the bioconjugates required to be internalized through receptor-mediated endocytosis. Furthermore, our results showed that apoptosis was also involved in the antitumor activity of the two bioconjugates, as indicated by the expression levels of the cleaved (active) form of caspase-3 in DU145 cells.

Taken together, these results demonstrate that the Dau-GnRH-III and Dau-[ ${ }^{4}$ Lys(Ac)]-GnRH-III bioconjugates exert a significant antitumor activity on human castrationresistant prostate cancer cells. Similar results with these two bioconjugates were previously reported in MCF-7 human breast cancer, HT-29 human colon and LNCaP human androgen-dependent prostate cancer cells in vitro, as well as on colon carcinoma-bearing mice $(14,35)$. The observation that GnRH-R targeted bioconjugates are effective in reducing the proliferation of CRPC cells is in line with data previously reported with two different cytotoxic GnRHderivatives: AEZS-108 (doxorubicin-[D-Lys $\left.\left.{ }^{6}\right]-G n R H\right)$ (36) and gemcitabine-[D-Lys $\left.{ }^{6}\right]-$ GnRH derivative (37).

The efficacy of peptide-based drugs is strongly dependent on their stability against enzyme-catalyzed hydrolysis during transport (e.g., blood circulation, digestive tract) as well as on their degradation by lysosomal enzymes. As underlined in Introduction, the oxime bond-linked daunorubicin-GnRH-III derivative bioconjugates have been previously shown to be stable in human serum at least for $24 \mathrm{~h}$. Moreover, the replacement of ${ }^{4}$ Ser by Lys(Ac) led to enhanced stability in the presence of digestive enzymes (in particular, against chymotrypsin). On the other hand, they were degraded by rat liver lysosomal enzymes; the smallest drug containing metabolite obtained in the presence of lysosomal enzymes was H-Lys(Dau=Aoa)-OH, which was shown to bind to DNA in vitro $(14,15)$. These properties clearly support the suitability of these two bioconjugates as targeted chemotherapeutics for tumors expressing the GnRH-R, including castration-resistant prostate cancer.

It is still unclear through which receptor GnRH-III might exert its antitumor activity on human cells. Here we provide evidence that, in DU145 cells, the cytostatic effect of both Dau-GnRH-III and Dau-[ $\left.{ }^{4} \mathrm{Lys}(\mathrm{Ac})\right]-\mathrm{GnRH}-\mathrm{III}$ is completely counteracted by the simultaneous treatment of the cells with Antide, a well known antagonist of the type I GnRH-R, the classical form of the GnRH-R. More importantly, we show that the antitumor activity of the two bioconjugates is 
completely abrogated in cells in which the type I GnRH-R has been silenced by siRNA technique. This clearly demonstrates that oxime bond-linked daunorubicin-GnRH-III derivative bioconjugates exert their strong antitumor activity on CRPC cells through the activation of the classical isoform of the GnRH-R. In agreement with our observations, Hegedüs and coworkers have reported that both these compounds inhibit the binding of $\left[{ }^{125} \mathrm{I}\right] \mathrm{GnRH}-\mathrm{I}$ to the membranes of human pituitary and human prostate cancer specimens (38).

The existence of a GnRH-R isoform different from the classical type I isoform in humans is still a matter of debate. Since the discovery of a second form of the GnRH peptide (GnRH-II) in most vertebrates, including humans, the existence of a putative cognate type II GnRH-R has been speculated. However, the human type II GnRH-R gene carries a frameshift and a premature stop codon, indicating that a functional full-length receptor protein does not exist in humans $(3,39)$. The results reported here, together with these observations, further sustain the notion that it is only the classical form of the GnRH-R that mediates the biological effects of the different $\mathrm{GnRH}$ isoforms (including GnRH-III) in humans.

In conclusion, our results demonstrate that cytotoxic GnRH-III-based bioconjugates can exert a specific antiproliferative/proapoptotic activity on castration-resistant prostate cancer cells and that this antitumor effect is specifically mediated by the type I GnRH-R. These data provide a basis for further development of targeted cancer chemotherapeutics.

Of particular interest are the so-called 'multi-functional' or 'multi-target' bioconjugates, in which two anticancer drugs with different mechanisms of action are attached to the same GnRH-III-based targeting moiety. Such compounds containing both methotrexate and daunorubicin attached to the same GnRH-III targeting moiety have recently been reported. They were shown to exert a higher in vitro cytostatic effect on breast, colon and hormone-dependent prostate cancer cells than the 'mono-functional' bioconjugates containing only one anticancer drug (40). The combination of two anticancer drugs in one bioconjugate targeting GnRH-R could be advantageous in the treatment of hormone-independent tumors such as castration-resistant prostate cancer; this issue will be addressed in further studies.

\section{Acknowledgements}

This study was supported by a research grant from the Zukunftskolleg, University of Konstanz, (Project 879/08).

\section{References}

1. Schally AV, Arimura A, Baba Y, Nair RM, Matsuo H, Redding TW and Debeljuk L: Isolation and properties of the FSH and LH-releasing hormone. Biochem Biophys Res Commun 43: 393-399, 1971.

2. Kakar SS, Malik MT, Winters SJ and Mazhawidza W: Gonadotropin-releasing hormone receptors: structure, expression, and signaling transduction. Vitam Horm 69: 151-207, 2004.

3. Millar RP: GnRHs and GnRH receptors. Anim Reprod Sci 88: $5-28,2005$

4. Emons G and Schally AV: The use of luteinizing hormone releasing hormone agonists and antagonists in gynaecological cancers. Hum Reprod 9: 1364-1379, 1994.

5. Labrie F, Belanger A, Luu-The V, et al: Gonadotropin-releasing hormone agonists in the treatment of prostate cancer. Endocr Rev 26: 361-379, 2005.
6. Imai A and Tamaya T: GnRH receptor and apoptotic signaling. Vitam Horm 59: 1-33, 2000.

7. Grundker C, Gunthert AR, Westphalen S and Emons G: Biology of the gonadotropin-releasing hormone system in gynecological cancers. Eur J Endocrinol 146: 1-14, 2002.

8. Montagnani Marelli M, Moretti RM, Januszkiewicz-Caulier J, Motta $\mathrm{M}$ and Limonta P: Gonadotropin-releasing hormone $(\mathrm{GnRH})$ receptors in tumors: a new rationale for the therapeutical application of GnRH analogs in cancer patients? Curr Cancer Drug Targets 6: 257-269, 2006.

9. Limonta P, Montagnani Marelli M, Mai S, Motta M, Martini L and Moretti RM: GnRH receptors in cancer: from cell biology to novel targeted therapeutic strategies. Endocr Rev 33: 784-811, 2012.

10. Limonta P and Manea M: Gonadotropin-releasing hormone receptors as molecular therapeutic targets in prostate cancer: Current options and emerging strategies. Cancer Treat Rev 39: 647-663, 2013.

11. Engel J, Emons G, Pinski J and Schally AV: AEZS-108 : a targeted cytotoxic analog of LHRH for the treatment of cancers positive for LHRH receptors. Expert Opin Investig Drugs 21: 891-899, 2012.

12. Kovacs M, Seprodi J, Koppan M, Horvath JE, Vincze B, Teplan I and Flerko B: Lamprey gonadotropin hormone-releasing hormone-III has no selective follicle-stimulating hormonereleasing effect in rats. J Neuroendocrinol 14: 647-655, 2002.

13. Szabo I, Manea M, Orban E, et al: Development of an oxime bond containing daunorubicin-gonadotropin-releasing hormone-III conjugate as a potential anticancer drug. Bioconjug Chem 20: 656-665, 2009.

14. Manea M, Leurs U, Orban E, et al: Enhanced enzymatic stability and antitumor activity of daunorubicin-GnRH-III bioconjugates modified in position 4. Bioconjug Chem 22: 1320-1329, 2011.

15. Orban E, Mezo G, Schlage P, et al: In vitro degradation and antitumor activity of oxime bond-linked daunorubicin-GnRH-III bioconjugates and DNA-binding properties of daunorubicinamino acid metabolites. Amino Acids 41: 469-483, 2011.

16. Schlage P, Mezo G, Orban E, Bosze S and Manea M: Anthracycline-GnRH derivative bioconjugates with different linkages: synthesis, in vitro drug release and cytostatic effect. J Control Release 156: 170-178, 2011.

17. Siegel R, Ma J, Zou Z and Jemal A: Cancer statistics, 2014. CA Cancer J Clin 64: 9-29, 2014.

18. Akaza H: Combined androgen blockade for prostate cancer: review of efficacy, safety and cost-effectiveness. Cancer Sci 102: 51-56, 2011.

19. Fitzpatrick JM: Management of castration-resistant prostate cancer: a call to urologists. BJU Int 110: 772-774, 2012.

20. Lee DJ, Cha EK, Dubin JM, et al: Novel therapeutics for the management of castration-resistant prostate cancer (CRPC). BJU Int 109: 968-985, 2012.

21. Dondi D, Limonta P, Moretti RM, Montagnani Marelli M, Garattini E and Motta M: Antiproliferative effects of luteinizing hormone-releasing hormone (LHRH) agonists on human androgen-independent prostate cancer cell line DU 145: evidence for an autocrine-inhibitory LHRH loop. Cancer Res 54: 4091-4095, 1994.

22. Dondi D, Moretti RM, Montagnani Marelli M, et al: Growthinhibitory effects of luteinizing hormone-releasing hormone (LHRH) agonists on xenografts of the DU 145 human androgenindependent prostate cancer cell line in nude mice. Int J Cancer 76: 506-511, 1998.

23. Limonta P, Moretti RM, Montagnani Marelli M, Dondi D, Parenti $\mathrm{M}$ and Motta $\mathrm{M}$ : The luteinizing hormone-releasing hormone receptor in human prostate cancer cells: messenger ribonucleic acid expression, molecular size, and signal transduction pathway. Endocrinology 140: 5250-5256, 1999.

24. Montagnani Marelli M, Moretti RM, Mai S, Procacci P and Limonta P: Gonadotropin-releasing hormone agonists reduce the migratory and the invasive behavior of androgen-independent prostate cancer cells by interfering with the activity of IGF-I. Int J Oncol 30: 261-271, 2007.

25. Montagnani Marelli M, Moretti RM, Mai S, JanuszkiewiczCaulier J, Motta M and Limonta P: Type I gonadotropin-releasing hormone receptor mediates the antiproliferative effects of GnRH-II on prostate cancer cells. J Clin Endocrinol Metab 94: 1761-1767, 2009.

26. Gnanapragasam VJ, Darby S, Khan MM, Lock WG, Robson CN and Leung HY: Evidence that prostate gonadotropin-releasing hormone receptors mediate an anti-tumourigenic response to analogue therapy in hormone refractory prostate cancer. J Pathol 206: 205-213, 2005. 
27. Liu SV, Schally AV, Hawes D, et al: Expression of receptors for luteinizing hormone-releasing hormone (LH-RH) in prostate cancers following therapy with LH-RH agonists. Clin Cancer Res 16: 4675-4680, 2010.

28. Palyi I, Vincze B, Lovas S, et al: Gonadotropin-releasing hormone analogue conjugates with strong selective antitumor activity. Proc Natl Acad Sci USA 96: 2361-2366, 1999.

29. Hong SW, Shin JS, Moon JH, et al: NVP-BEZ235, a dual $\mathrm{PI} 3 \mathrm{~K} / \mathrm{mTOR}$ inhibitor, induces cell death through alternate routes in prostate cancer cells depending on the PTEN genotype. Apoptosis 19: 895-904, 2014.

30. Engel JB, Schally AV, Buchholz S, Seitz S, Emons G and Ortmann O: Targeted chemotherapy of endometrial, ovarian and breast cancers with cytotoxic analogs of luteinizing hormonereleasing hormone (LHRH). Arch Gynecol Obstet 286: 437-442, 2012.

31. Emons G, Gorchev G, Harter P, et al: Efficacy and safety of AEZS-108 (LHRH agonist linked to doxorubicin) in women with advanced or recurrent endometrial cancer expressing LHRH receptors: a multicenter phase 2 trial (AGO-GYN5). Int J Gynecol Cancer 24: 260-265, 2014.

32. Szepeshazi K, Schally AV, Keller G, et al: Receptor-targeted therapy of human experimental urinary bladder cancers with cytotoxic LH-RH analog AN-152 [AEZS-108]. Oncotarget 3: 686-699, 2012

33. Jaszberenyi M, Schally AV, Block NL, Nadji M, Vidaurre I, Szalontay L and Rick FG: Inhibition of U-87 MG glioblastoma by AN-152 (AEZS-108), a targeted cytotoxic analog of luteinizing hormone-releasing hormone. Oncotarget 4: 422-432, 2013.
34. Szepeshazi K, Schally AV, Block NL, et al: Powerful inhibition of experimental human pancreatic cancers by receptor targeted cytotoxic LH-RH analog AEZS-108. Oncotarget 4: 751-760, 2013.

35. Manea M, Tovari J, Tejeda M, Schulcz A, Kapuvari B, Vincze B and Mezo G: In-vivo antitumour effect of daunorubicinGnRH-III derivative conjugates on colon carcinoma-bearing mice. Anticancer Drugs 23: 90-97, 2012.

36. Letsch M, Schally AV, Szepeshazi K, Halmos G and Nagy A: Preclinical evaluation of targeted cytotoxic luteinizing hormonereleasing hormone analogue $\mathrm{AN}-152$ in androgen-sensitive and insensitive prostate cancers. Clin Cancer Res 9: 4505-4513, 2003.

37. Karampelas T, Argyros O, Sayyad N, et al: GnRH-gemcitabine conjugates for the treatment of androgen-independent prostate cancer: pharmacokinetic enhancements combined with targeted drug delivery. Bioconjug Chem 25: 813-823, 2014.

38. Hegedüs R, Manea M, Orbán E, et al: Enhanced cellular uptake and in vitro antitumor activity of short-chain fatty acid acylated daunorubicin-GnRH-III bioconjugates. Eur J Med Chem 56: 155-165, 2012.

39. Cheng CK and Leung PC: Molecular biology of gonadotropinreleasing hormone (GnRH)-I, GnRH-II, and their receptors in humans. Endocr Rev 26: 283-306, 2005.

40. Leurs U, Lajko E, Mezo G, et al: GnRH-III based multifunctional drug delivery systems containing daunorubicin and methotrexate. Eur J Med Chem 52: 173-183, 2012. 